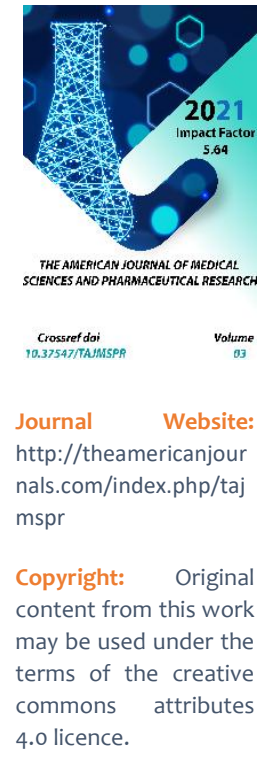

\title{
The Role Of rs1799883 Polymorphism Of The FABP2 Gene In The Pathogenesis Of Nosological Syntropy Of Gallstone Disease And Metabolic Syndrome
}

\author{
Raximov Anvar Pulatboevich \\ Assistant, Urgench Branch Of The Tashkent Medical Academy, Urgench, Uzbekistan \\ Ismailov O'ktam Safaevich \\ Doctor Of Medical Sciences, Professor, Tashkent Medical Academy, Tashkent, Uzbekistan \\ Batirov Davronbek Yusupovich \\ Candidate Of Medical Sciences, Associate Professor, Urgench Branch Of The Tashkent \\ Medical Academy, Urgench, Uzbekistan
}

\section{ABSTRACT}

Objective: to study the role of the $\mathrm{r} \$ 1799883$ polymorphism of the FABP2 gene in the pathogenesis of gallstone disease in combination with MS. Material and methods. Molecular genetic studies were carried out in the Department of Molecular Medicine and Cell Technologies of the RSNPMC Hematology.

The analysis of the associations of the rs1799883 polymorphisms of the FABP2 gene was carried out using a case-control model.

The main group consisted of 118 patients with cholelithiasis in combination with MS living in the Khorezm region.

Results: As a result of our research, we identified a significant association of the homozygous genotype for the Thr allele with the development of gallstone disease in combination with MS. The indicator of the ratio of the chances of developing gallstone disease in combination with MS in carriers of this genotype was $\mathrm{OR}=2.9$ at $95 \% \mathrm{Cl}: 1.122-7.424$. The relative risk of disease was $\mathrm{RR}=2.5$ with $95 \% \mathrm{Cl}: 1.11-5.76$.

Conclusion: Our results allow us to conclude that the homozygous Thr/Thr genotype plays an important role in the formation of gallstone disease and obesity in people of Uzbek nationality.

\section{KEYWORDS}

Gallstone disease, metabolic syndrome, FABP2, Ala54Thr, polymorphism, gene, allele, genotype, pathogenesis, obesity. 


\section{INTRODUCTION}

Cholelithiasis (GSD) and metabolic syndrome (MS) are widespread in the human population: $10-15 \%$ are patients with cholelithiasis, $15-25 \%$ are patients with MS, in both cases, there is a tendency towards rejuvenation and a progressive increase in the number of patients $[1,4,7,8,9]$.

The prevalence of MS and associated with gallstones in the modern world has acquired a pandemic. It has been proven that MS is not only a risk factor for the manifestation of gallstone disease but also its complicated course $[2,3]$.

The main pathogenetic risk factors for gallstone disease with a combination of MS include the genetic background. According to various sources, genetic factors in the formation of gallstones and associated with MS are from 50 to $85 \%[6,7,8]$.

Scientific research on the human genome with cholelithiasis in combination with MS makes it possible to predict the development of comorbid pathology and thereby improve the results of primary prevention. The introduction of molecular genetics methods into clinical practice will make it possible to assess the risk of developing cholelithiasis with a combination of MS and the peculiarities of its course $[4,9]$.

Therefore, in recent years, more and more attention of researchers is directed to the study of the genetic basis of gallstone disease in combination with MS. According to the literature, in the pathogenesis of MS, an important role is assigned to the violation of lipid metabolism $[2,8]$. The FABP2 gene plays an important role in the regulation of the formation of metabolic disorders [7,12].

The FABP2 gene, as a lipolytic receptor in human adipose cells, is associated with lipid mobilization [12, 14]. The most common polymorphism is considered to be Ala54Thr (rs1799883). Considering the relationship of the rs1799883 allelic polymorphism of the $\mathrm{FABP} 2$ gene with the clinical and functional characteristics of metabolic disorders, it can be assumed that it is involved in the nosological syntropy of gallstone disease and metabolic syndrome. Identification of genotypic variants of this locus, affecting lipid metabolism disorders, makes it possible to assess the individual risk of developing MS in patients with cholelithiasis.

Objective: to study the role of the rs1799883 polymorphism of the $\mathrm{FABP}_{2}$ gene in the pathogenesis of gallstone disease in combination with MS.

\section{MATERIALS AND METHODS}

Molecular genetic studies were carried out in the Department of Molecular Medicine and Cell Technologies of the RSNPMC Hematology. The analysis of the associations of the rs1799883 polymorphisms of the FABP2 gene was carried out using a case-control model. The main group consisted of 118 patients with cholelithiasis in combination with MS living in the Khorezm region. Among 118 patients, women accounted for $63.6 \%$ (75 patients) and $36.4 \%$ - men (43 patients) aged 24 to 73 years. All examined patients were divided into 3 subgroups: Subgroup - A 58 patients with cholelithiasis with a combination of obesity, subgroup - B 27 patients with cholelithiasis with a combination of diabetes mellitus (DM) and 33 patients with cholelithiasis without MS in subgroup B. As a material for the control sample, we used preparations of genomic DNA ( $n=120)$, conditionally healthy unrelated donors of Uzbek nationality and had no history of gallstone disease and MS. 


\section{RESULTS AND DISCUSSION}

Table 1 shows the results of a comparative analysis of the frequencies of distribution of alleles and genotypes of the rs1799883 polymorphism of the $\mathrm{FABP} 2$ gene in the general group and subgroups of patients with gallstone disease and the control sample.

In both groups, the actual distribution of the rs1799883 polymorphism genotypes corresponded to those expected at HardyWeinberg equilibrium (RHB). The frequency of Ala and Thr alleles, respectively, was 0.68/0.32 in the patient group and $0.78 / 0.22$ in the control group.

In the main group of patients, the observed and expected frequencies of Ala/Ala, Ala/Thr and Thr/Thr genotypes were 0.49/0.46, $0.37 / 0.44$ and $0.14 / 0.10$, respectively.

In the comparative group, the frequency of these genotypes was $0.62 / 0.61,0.32 / 0.34$, and $0.06 / 0.05$. As can be seen, in both groups studied, the difference between the expected and observed frequencies of genotypes was statistically insignificant $\left(\chi^{2}<3.85 ; P>0.05\right)$.

The distribution frequency of Ala and Thr alleles in the studied samples was $67.8 \%$ and
$32.2 \%$ versus $77.1 \%$ and $22.9 \%$, respectively. The chance of detecting an unfavourable Thr allele among patients is significantly increased by more than 1.5 times compared with the control group $\left(\chi^{2}=5.1 ; P=0.02 ; O R=1.6 ; 95 \%\right.$ $\mathrm{Cl}$ 1.064-2.399). The study of the distribution of genotypes showed that the dominant genotype in the studied groups of patients and controls was the homozygous genotype Ala/Ala, the frequency of which was $49.1 \%$ and $61.7 \%$, respectively. The distribution of heterozygous Ala/Thr and unfavourable Thr/Thr genotypes in the studied groups of patients was recorded - $37.3 \%$ and $13.6 \%$, respectively, in the control group - $30.8 \%$ and 7.5\%, respectively (Tables $1-2$ ).

There was a significant difference in the frequency of distribution of the unfavourable Thr allele and the minor Thr/Thr genotype between the subgroups of obese patients and the control sample (Table 3). According to the odds ratio, the risk of obesity in the presence of an unfavourable Thr/Thr genotype significantly increases by more than 3.0 times $\left(X^{2}=5.1 ; \mathrm{P}=0.02 ; \mathrm{OR}=2.9 ; 95 \% \mathrm{Cl} 1.122-7.424\right)$.

Table 1. Frequency of distribution of alleles and genotypes of rs1799883 polymorphism of the FABP2 gene in patient and control groups

\begin{tabular}{|c|c|c|c|c|c|c|c|c|c|c|c|}
\hline \multirow{2}{*}{ № } & \multirow{2}{*}{ Group } & \multicolumn{3}{|c|}{ Allele frequency } & \multicolumn{3}{c|}{ Genotype distribution frequency } \\
\cline { 2 - 14 } & \multicolumn{2}{|c|}{ Ala } & \multicolumn{2}{|c|}{ Thr } & \multicolumn{2}{c|}{ Ala/Ala } & \multicolumn{2}{|c|}{ Ala/Thr } & \multicolumn{2}{|c|}{ Thr/Thr } \\
\cline { 2 - 13 } & $\mathrm{n}$ & $\%$ & $\mathrm{n}$ & $\%$ & $\mathrm{n}$ & $\%$ & $\mathrm{n}$ & $\%$ & $\mathrm{n}$ & $\%$ \\
\hline 1 & Main group n = 118 & 160 & 67.8 & 76 & 32.2 & 58 & 49.1 & 44 & 37.3 & 16 & 13.6 \\
\hline a & $\begin{array}{c}\text { Obese gallstone } \\
\text { disease } \mathrm{n}=58\end{array}$ & 73 & 62.9 & 43 & 37.1 & 26 & 44.8 & 21 & 36.2 & 11 & 19.0 \\
\hline
\end{tabular}




\begin{tabular}{|c|c|c|c|c|c|c|c|c|c|c|c|}
\hline 6 & ZhKB with SD n = 27 & 37 & 68.5 & 17 & 31.5 & 13 & 48.1 & 11 & 40.7 & 3 & 11.1 \\
\hline B & $\begin{array}{c}\text { ZhKB without MS n = } \\
33\end{array}$ & 50 & 75.8 & 16 & 24.2 & 19 & 57.6 & 12 & 36.4 & 2 & 6.1 \\
\hline 2 & $\begin{array}{c}\text { Counter. group n = } \\
120\end{array}$ & 185 & 77.1 & 55 & 22.9 & 74 & 61.7 & 37 & 30.8 & 9 & 7.5 \\
\hline
\end{tabular}

Table 2. Differences in the frequency of allelic and genotypic variants of rs1799883 polymorphism of the FABP2 gene in the study group and the control sample

\begin{tabular}{|c|c|c|c|c|c|c|c|c|c|c|}
\hline \multirow{3}{*}{$\begin{array}{l}\text { Alleles and } \\
\text { genotypes }\end{array}$} & \multicolumn{4}{|c|}{$\begin{array}{c}\text { Number of examined alleles and } \\
\text { genotypes }\end{array}$} & \multirow{3}{*}{$x^{2}$} & \multirow{3}{*}{$P$} & \multirow{3}{*}{$\mathrm{RR}$} & \multirow{3}{*}{$95 \% \mathrm{Cl}$} & \multirow{3}{*}{ OR } & \multirow{3}{*}{$95 \% \mathrm{Cl}$} \\
\hline & \multicolumn{2}{|c|}{ Main group } & \multicolumn{2}{|c|}{ Control } & & & & & & \\
\hline & $\mathrm{n}$ & $\%$ & $\mathrm{n}$ & $\%$ & & & & & & \\
\hline Ala & 160 & 67.8 & 185 & 77.1 & \multirow{2}{*}{5.1} & \multirow{2}{*}{0.02} & \multirow{2}{*}{1.4} & \multirow{2}{*}{$\begin{array}{c}1.044^{-} \\
1.891\end{array}$} & \multirow{2}{*}{1.6} & $1.064-$ \\
\hline Thr & 76 & 32.2 & 55 & 22.9 & & & & & & 2.399 \\
\hline Ala/Ala & 58 & 49.1 & 74 & 61.7 & 3.8 & 0.05 & 0.8 & $\begin{array}{l}0.632- \\
1.005\end{array}$ & 0.6 & $\begin{array}{c}0.3589- \\
1.006 \\
\end{array}$ \\
\hline Ala/Thr & 44 & 37.3 & 37 & 30.8 & 1.1 & 0.2 & 1.2 & $\begin{array}{c}0.8473^{-} \\
1.726 \\
\end{array}$ & 1.3 & $\begin{array}{c}0.7789- \\
2.284 \\
\end{array}$ \\
\hline Thr/Thr & 16 & 13.6 & 9 & 7.5 & 2.1 & 0.1 & 1.8 & $\begin{array}{l}0.832- \\
3.928\end{array}$ & 1.9 & $\begin{array}{c}0.8189- \\
4.571\end{array}$ \\
\hline
\end{tabular}

It is interesting to note that a clear relationship between the risk of developing cholelithiasis with DM and the distribution of predisposing genotypic variants of the rs1799883 polymorphism of the FABP2 gene has not been established, which does not allow the use of this locus as a genetic marker for predicting the risk of developing this combination $(P>0.05)$.

Table 3. Differences in the frequency of allelic and genotypic variants of the rs1799883 polymorphism of the FABP2 gene in subgroup $A$ of patients and the control group

\begin{tabular}{|c|c|c|c|c|c|c|c|c|c|c|}
\hline \multirow{3}{*}{$\begin{array}{l}\text { Alleles and } \\
\text { genotypes }\end{array}$} & \multicolumn{4}{|c|}{$\begin{array}{c}\text { Number of examined alleles } \\
\text { and genotypes }\end{array}$} & \multirow{3}{*}{$x^{2}$} & \multirow{3}{*}{$P$} & \multirow{3}{*}{ RR } & \multirow{3}{*}{$95 \% \mathrm{Cl}$} & \multirow{3}{*}{ OR } & \multirow{3}{*}{$95 \% \mathrm{Cl}$} \\
\hline & \multicolumn{2}{|c|}{ Subgroup A } & \multicolumn{2}{|c|}{ Control } & & & & & & \\
\hline & $n$ & $\%$ & $\mathrm{n}$ & $\%$ & & & & & & \\
\hline Ala & 73 & 62.9 & 185 & 77.1 & \multirow{2}{*}{7.8} & \multirow{2}{*}{0.005} & \multirow{2}{*}{1.6} & 1.161- & \multirow{2}{*}{2.0} & $1.223-$ \\
\hline Thr & 43 & 37.1 & 55 & 22.9 & & & & 2.254 & & 3.209 \\
\hline
\end{tabular}




\begin{tabular}{|c|c|c|c|c|c|c|c|c|c|c|}
\hline Ala/Ala & 26 & 44.8 & 74 & 61.7 & 4.5 & 0.03 & 0.7 & $\begin{array}{c}0.5287- \\
0.999\end{array}$ & 0.5 & $\begin{array}{c}0.2677- \\
0.953\end{array}$ \\
\hline Ala/Thr & 21 & 36.2 & 37 & 30.8 & 0.5 & 0.5 & 0.2 & $\begin{array}{c}0.7607- \\
1.813\end{array}$ & 1.3 & $\begin{array}{c}0.6575^{-} \\
2.466\end{array}$ \\
\hline Thr/Thr & 11 & 19.0 & 9 & 7.5 & 5.1 & 0.02 & 2.5 & $1.11-5.76$ & 2.9 & $\begin{array}{c}1.122- \\
7.424\end{array}$ \\
\hline
\end{tabular}

Thus, as a result of the study, an association of the functionally unfavourable Thr/Thr genotype of the rs1799883 polymorphism of the $\mathrm{FABP} 2$ gene with the severity of gallstone disease was noted. This genotypic variant is more typical for obese patients with gallstone disease. With this Thr/Thr genotype, the chance of gallstone formation + obesity significantly increases by more than 3.0 times with a $95 \% \mathrm{Cl}$ confidence interval of 1.122-7.424 $\left(x_{2}=5.1\right.$ and $\left.p=0.02\right)$ in relation to other genotypic variants. Unfortunately, when analyzing the literature, we were unable to find works devoted to the analysis of the role of the rs1799883 polymorphism of the FABP2 gene in the etiopathogenesis of gallstone disease in combination with MS. At the same time, works devoted to the role of FABP2 polymorphic variants in susceptibility to the development of obesity. Barodina S. et al. (2016) found the rs1799883 polymorphism to be more common in overweight people, while Erenborg (2004) found it was associated with only mild to moderately elevated BMI. Fehel T. (2012) did not find any relationship between this locus and the development of MS $[13,14]$.

The results we obtained are consistent with those of the researchers Zang $H$ [12]. But, nevertheless, Zang $H$. found that the heterozygous Ala/Thr genotype would also lead to obesity. In our studies, it was found that when comparing gallstones with obesity and conventionally healthy people, the heterozygous genotype is almost the same.

\section{CONCLUSION}

Our results allow us to conclude that the homozygous Thr/Thr genotype plays an important role in the pathogenesis of nosological syntropy of cholelithiasis and metabolic syndrome. The risk of developing gallstones with MS in the presence of this genotypic variant of the FABP2 gene can significantly increase by more than 3.0 times.

\section{REFERENCES}

1. Akhmedov, V.A., \& Gaus, O.V. (2019). Modern ideas about the mechanisms of development and management tactics of patients with cholelithiasis associated with metabolic syndrome. Medical Alphabet, 2 (13), 52-56.

2. Dorofeeva S.G., Konoplya E.N., Mansimova O.V., Shelukhina A.N., Anyushonkov O.S. (2020). Cholelithiasis: modern concepts of aetiology and pathogenesis. Integrative trends in medicine and education. 2. pp. 21-25.

3. Zelenskaya, E.M., Koh, N.V., Slepukhina, A.A., \& Lifshits, G.I. (2017). Nutrigenetic test in clinical practises: goals and opportunities. Clinical practice, (3 (31)).

4. Sagdatova, A. A., Zulkarneev, R. Kh., Khusnutdinova, E. K., Nurgalieva, A. Kh., \& Zagidullin, Sh. Z. (2017). Multifactorial 
clinical and genetic model of the development of gallstone disease. Practical medicine, (6 (107)).

5. Khokhlacheva, N.A., Kosareva, T.S., \& Lukashevich, A.P. (2020). New approaches to the study of the prevalence of gallstone disease. Archive of Internal Medicine, 10 (4 (54)).

6. Shutova, E. V. (2016). Apolipoprotein e gene polymorphism and lipid metabolism disorders in children with cholelithiasis. Child health, (5 (73)).

7. Baratta, F., Pastori, D., Cocomello, N., Colantoni, A., Ferro, D., Angelico, F., \& Del Ben, M. (2021). Sex-Related Differences in the Association between Metabolic Syndrome and Gallstone Disease. International journal of environmental research and public health, 18(4), 1958.

8. Chauhan, T., Mittal, R. D., \& Mittal, B. (2020). Association of Common Single Nucleotide Polymorphisms of Candidate Genes with Gallstone Disease: A MetaAnalysis. Indian Journal of Clinical Biochemistry, 35(3), 290-311.

9. Li, L., Qiao, X., Wang, X., Liu, D., Xue, Q., Han, L., ... \& Yang, J. (2019). The association between apolipoprotein $E$ and gallstone disease: an updated metaanalysis. BMC medical genetics, 20(1), 1-9.

10. Sheng, B., Zhao, Q., Ma, M., \& Zhang, J. (2020). An inverse association of weight and the occurrence of asymptomatic gallbladder stone disease in hypercholesterolemia patients: a casecontrol study. Lipids in Health and Disease, 19(1), 1-10.

11. Stender, S., Frikke-Schmidt, R., Benn, M., Nordestgaard, B. G., \& Tybjærg-Hansen,
A. (2013). Low-density lipoprotein cholesterol and risk of gallstone disease: a Mendelian randomization study and meta-analyses. Journal of hepatology, 58(1), 126-133.

12. Zhang, H., Wu, J., \& Yu, L. (2014). Association of Gln27Glu and Arg16Gly polymorphisms in Betaz-adrenergic receptor gene with obesity susceptibility: a meta-analysis. PLoS One, 9(6), e100489.

13. Бородина, С. В., Гаппарова, К. М., Зайнудинов, 3. М., \& Григорьян, О. Н. (2016). Генетические предикторы развития ожирения. Ожирение $u$ метаболизм, 13(2).

14. Feher Turkovic, L., Pizent, A., Dodig, S., Pavlovic, M., \& Pasalic, D. (2012). FABP 2 gene polymorphism and metabolic syndrome in elderly people of Croatian descent. Biochemia Medica, 22(2), 217-224. 